\title{
CONTEMPORARY ORGANISATIONAL CHANGE AND THE IMPORTANCE OF TRUST
}

\author{
NEVILLE BEWS \\ Department of Sociology \\ Rand Afrikaans University \\ DEON ROSSOUW \\ Department of Philosophy \\ Rand Afrikaans University
}

\begin{abstract}
Over the last two decades the rate of social change has been so rapid that there are those who have announced the arrival of a whole new era. For this special edition of the South African Journal of Industrial Psychology, this paper examines some of these changes, as they are unfolding over two fronts. Firstly, the extent of change in respect of the transformation of work is considered. Secondly the manner in which employees are responding to these changes is examined. These changes are then related to the phenomenon of organisational trust and the importance of organisational trust within contemporary society.
\end{abstract}

\section{OPSOMMING}

Sosiale verandering oor die afgelope twee decades het teen so ' $n$ tempo plaasgeving dat sommige beweer dat ' $n$ nuwe era aangebreek het. Met die oog op hierdie spesiale uitgawe van die South African Journal of Industrial Psychology/ Suid Afrikaanse Tydskrif vir Bedryfsielkunde verken hierdie artikel sommige van die veranderinge soos wat dit veral op twee fronte ontvou het. Eerstens word gekyk na die omvang van die transformasie van werk. Tweedens word die wyse waarop werkers op hierdie transformasie reageer, ondersoek. Hierdie veranderinge word daarna in verband gebring met die verskynsel van vertroue in organisasies asook met die belangrikheid van sodanige vertroue in die huidige tydsgewrig.

For nearly a century social theorists have been debating the arrival of a whole new era. As far back as 1914, Arthur J. Plenty and Ananda K. Coomaraswamy made reference to the postindustrial. In the preface to his 1922 work Post-Industrialism, Plenty referred to the post-industrial as that "... state of society that will follow the break-up of Industrialism" (Rose, 1991, p. 23). Predicting a more gradual change, Drucker (1969), Bell (1973) and Toffler (1980) all used the concept "post-industrial" to refer to the arrival of a whole new era replacing that of the industrial. A third position is that there is no continuity between the industrial and the post-industrial and that reference should rather be made to the "late", "super" or "hyper" industrial but not the post-industrial (Kumar, 1995).

Whether industrial society has in fact undergone such fundamental and far-reaching change that we can now legitimately speak of a whole new era remains debatable. What is, however, clear is that industrial society is indeed experiencing change on a major scale and that this change seems to accelerate with time. The period following the Second World War, for example, saw major expansion, largely of a technological nature, occurring on both the quantitative and qualitative levels. This rate of change, never previously experienced, was driven by the War, accelerated by the Space Race with the launch of Sputnik in 1957, and highlighted by the American landing on the moon in 1969.

This momentum was interrupted when the oil crisis struck the world in 1973, resulting in attention being turned towards "the limits of growth" rather than remaining on expansionism (Kumar, 1995, p. 2). Consequently, the expansionism of the 1960s was replaced by a sense of reductionism, caution, stress and conflict. By the mid 1980s, though, and throughout the '90s, developments in the information technology (IT) industry brought about a more specific and limited resurgence. Although this resurgence may have resulted in the emergence of globalisation, it in turn resulted in a much leaner, flexible organisational structure, the transformation of work, increasing job losses and the appearance of the knowledge

Requests for copies should be addressed to: D Rossouw, Department of Sociology, RAU, PO Box 594, Auckland Park, 2006. E-mail: bewsco@netactive.co.za worker (Bews, 2000; Handy, 1994; Howard, 1996; Von Holdt \& Webster, 2001).

This change has resulted in what has become a rather complex society, prompting Charles Handy's (1994) work The age of paradox in which he argues that the complex nature of emerging society is such that it has resulted in a number of paradoxes that contemporary organisations, and those working in these organisations, face on a daily basis. One such paradox concerns organisational trust, which is currently eroding at an alarming rate while at the same time it is being recognised as an important factor for success in these new organisational forms (Davis, Mayer \& Schoorman, 1995; Goman, 1991; Hiltrop, 1995; Horton \& Reid, 1991; Reina \& Reina, 1999). It is against this background that the transformation of work and the issue of organisational trust will be considered in this paper.

\section{The transformation of work}

Driven by globalisation and the need to remain responsive and flexible during a time of discontinuity, contemporary organisations are relying more heavily on technology, the knowledge worker and contract employment. Consequently, organisations throughout the world such as IBM, British Telecom, Siemens, Benetton and Telkom, amongst many others, have all reduced their staff complement or use contract workers on a large scale (Allard, 2000; Bews, 2000; Von Holdt \& Webster, 2001).

During the 1980s over 3.4 million jobs were lost from Fortune 500 companies in the USA and, of some 400 US companies surveyed, $80 \%$ had embarked on a downsizing exercise over a five year period stretching between 1986 and 1991 (Hall \& Mirvis, 1996, p. 234). This situation is not unique to the United States as there have been substantial job losses reported from the United Kingdom, Europe, Australia, Africa and even Japan, a country where life-long employment had, for many years, been considered by many as somewhat of a tradition.

In the United Kingdom, 57\% of employees were affected by redundancies between 1990 and 1995 (Schofield, 1993), not all of which were due to financial constraints. In the same vein, 
Webster (1995:148) points out that between 1993 and 1995 IBM cut its workforce by $25 \%$, and this at a time when IBM's income had doubled; British Telecom reduced its job complement by 100,000 jobs while over the same period increasing its revenue by over a fifth; and at British Petroleum, 132,000 employees lost their jobs just as the company showed a $20 \%$ increase in income. In Germany, Siemens reduced its workforce by 3,000 in 1993 while Krupp-Hoesch and Mercedes-Benz both reduced their management structures (Robbins, 1997:11).

Over a 12-year period 3.3 million workers were retrenched in Australia and although the Australian workforce has swelled, this increase in jobs is solely in terms of part-time work with permanent employment remaining stable between 1990 and 1997 (Cleary, 1997). Research undertaken at the University of Melbourne and reported in the Sydney Morning Herald found that “... retrenchments have risen by between 5 and 10 per cent during the "90s", despite the fact that incomes rise for those who keep their jobs as well as for shareholders and business owners (Allard, 2000:1).

In South Africa, a similar situation to that which was found in the United Kingdom and Australia prevails. This is indicated by the Top 100-97 report (Financial Mail, 1998) which indicates that in 1997, notwithstanding "... yet another year of expansion in [the South African] economy ...", employment figures on the Johannesburg Stock Exchange in the industrial sector "... showed a nett decline in the overall employment figures of the companies ranked". It also showed that, "[o]f the 174 industrial companies ranked, 71 or $40,6 \%$ employed fewer people at the end of their last financial years than they had a year earlier; 77 or just $44,3 \%$ increased their payrolls and 26 either showed no comparative figures or were unchanged."

The fact that the South African working environment has undergone a great deal of change, as organisations adapt in response to global changes, cannot be denied (Von Holdt $\&$ Webster, 2001). It is also quite clear that job losses are still on the increase in South Africa (Indicator SA, 2001, p. 28; Louw, 2001).

The reasons for the loss of these jobs are varied. Of the 12,000 workers used by the Italian clothing manufacturer Benetton, only 1,500 were permanently employed and the remainder were contract workers. This allowed Benetton to reduce staff without undertaking tedious procedures, thus giving the company the ability to rapidly adjust to market changes or, as Atkinson (1985) puts it, to practice "numerical flexibility". In the USA, technical developments in the form of bar codes led to the loss of 400,000 jobs in the retail industry alone (Howard, 1996:29). On a much broader scale, technical developments also affected most industries and resulted in the loss of millions of jobs worldwide. Globalisation has also been a factor, leading to numerous job losses, higher job insecurity and reduced promotional opportunities.

In this respect Von Holdt and Webster (2001, pp. 19-21) identify four emerging trends within the South African workplace, which they list as (1) a "limited market/sectorial decline"; (2) "growing competitive pressure"; (3) "casualisation, informalisation and sub-contracting" and (4) "privatisation of parastatals". They argue that these trend are largely due to globalisation and have resulted in significant job losses. They list companies such as Kelvinator, Fridge Master, PG Bison, Highveld Steel and Telkom as all having been affected. They also mention sectors, such as the leather sector, and industries, such as the mining industry, which have experienced significant job losses. The short-term insurance sector has also recently experienced large-scale restructurings and significant job losses with companies such as Protea Insurance, General Accident, Guardian National, and Commercial Union all being absorbed by either Santam or Mutual \& Federal, and SA Eagle undergoing significant restructuring.
As these changes unfold and both directly and indirectly affect a greater number of people, so society's perception of work changes. Employer-employee loyalty is eroded, individualism rises and the psychological contract of employment is modified in an attempt to cope with a changing working environment.

\section{Changing employee values}

Considering the changing nature of work, Hage (1996, p. 467) refers to a broad reaction which he labels the "... more complex, post-modern mind". He suggests that post-modernism is a change in the character of individuals' minds and their perception of reality and, as such, is an effect of post-industrial change, which includes new technologies and the transformation of work. He suggests that the complexities of post-modern society require individuals to be more complex, creative, adaptable and flexible and to have the ability to read symbolic communications. This contrasts with industrial society where the individual relied on well-defined role scripts.

Employees have reacted to changes within the work environment and are consequently changing their attitudes towards work. Research undertaken by Moskal (Robbins, 1997, p. 12) showed that $77 \%$ of the workers that they surveyed believed that companies showed less loyalty towards employees in 1993 than they did in 1988, while $60 \%$ believed employee loyalty towards the organisation had diminished. In some respects this diminishing level of employer-employee loyalty has put pressure on the traditional view of the employer-employee relationship.

In this regard, the so-called "Protestant work ethic" that encouraged a hard, honest day's work and which would be rewarded with regular salary increases, promotions and job security has collapsed. Companies can no longer make promises of life-long employment and employees are no longer prepared to place their careers in the hands of one or two employers. This has resulted in a serious examination of what has been referred to as the psychological contract of employment (Hiltrop, 1995; Horton \& Reid, 1991; Howard, 1996; Moss-Kanter, 1989). Employees are now placing greater emphasis on the development of their careers rather than limiting their career development by remaining loyal to two or three companies over the span of their careers. They are also more inclined to make career changes to make adjustments to improve their life styles or to cope with the demands of the changing nature of work, resulting in the phenomenon of the "protean career" (Hall, 1996).

In certain respects a greater emphasis is being placed on individualism in contemporary society. Taylor (1992) points out that as the individual withdraws from participation in preference to self-indulgence, this ultimately leads to powerlessness and alienation and creates a paradox of increasing individualism at the expense of civic freedom. The rise of individualism has eroded the collective influence of employees and, to some extent, may have advanced the decline of unionism, leaving employees to face the challenges of the changing world of work alone.

This self-indulgence has, however, also seen contemporary employees more disposed towards pursuing leisure and family activities than the workers of the fifties, sixties and seventies were. According to Hiltrop (1995, pp. 278-288) a survey undertaken by International Survey Research in the United Kingdom found that younger people are more concerned with life quality, tend to criticise authority, including their employers, more, seek challenges in their jobs and prefer jobs that are useful to society. On the other hand, older workers, especially those over 50, are more inclined to embrace the Protestant work ethic. Younger workers place a premium on independence, imagination, tolerance and responsibility. This finding contradicts Gini's (1998) argument that America, as a nation, currently suffers from workaholism and a decline of leisure, thus suggesting another paradox of our time. Gini bases his argument on the work done by Schor (in Gini, 1998, p. 711) 
and statistics obtained from the Federal Department of Labour, which indicate that blue/white collar workers work an average 50 hour week, that middle and upper managers work a 58 to 65 hour week, that $89 \%$ of Americans regularly take work home and that the projected average work week will, by the year 2010, amount to 58 hours.

What may seem to be a paradox could possibly be explained in three ways. First, the threat of retrenchments may motivate workers to work extraordinary hours in an attempt to secure their positions. Secondly, survivors may face additional responsibilities as the workforce shrinks while the workload remains stable or even increases. Thirdly, individuals may be inclined to work longer hours in an attempt to cope with an increasingly expensive life style.

A further paradox concerns the rise of individualism at a time when emphasis is being placed on an increasing need for teamwork within the new organisational structures. Hage (1996) contends that this greater emphasis on teamwork and creativity has led to emotional stress and, in turn, highlights the importance of leisure time activities to reduce burnout.

Traditional family assumptions have also been challenged as family forms change. Employees, many of whom are single parents, now need to cope with increasing pressures within a shrinking workforce. These pressures are caused by limited employment opportunities and, as Gonyea and Googins (1996) point out, increasing workloads as survivors take up additional responsibilities at one time allocated to now retrenched colleagues. The emergence of the dual career family has also resulted in a change of attitude amongst employees. Men are becoming more disposed towards promoting the careers of their partners and are more prepared to follow their partners, in the event of their partner's career showing greater potential than their own careers.

Diversity is also increasing in the workplace and minority groups are no longer simply prepared to be assimilated into the mainstream of the workforce but are insisting that their individuality be recognised. Attention is now being given to the advantages that diversity may bring to the workforce as organisations attempt to capture the creativity of a multicultural workforce (Lattimer, 1996, pp. 15-34). Diversity is, however, also causing tensions as organisations operate within a global economy and migrant labour intensifies. For instance, the German firm BMW recently acquired the British motor manufacturer Rolls Royce. Japanese motor vehicles are manufactured and sold throughout the world. The American companies Coca-Cola, McDonald's and Levi's operate on a global basis. Migrant labour occurs on a large scale as people, unable to secure jobs in their own country, offer their labour to those countries unable to secure cheap labour. Germany serves as a prime example of this phenomenon. A large part of the German labour force is made up of migrant labour from Turkey and Eastern Europe. Of the 3.4 million Turks living abroad, 2.04 million live in Germany according to the Republic of Turkey's Ministry of Foreign Affairs web site. This has led to the concept of "guest labour" in Germany.

Considering the extent of current social change it seems that employer-employee relationships are currently under threat from three fronts. Firstly, the emergence of what may eventually amount to a new era, that of the post-industrial, is resulting in diminishing job security, fewer job opportunities and lower levels of perceived employer loyalty. Secondly, employees are reacting by in turn showing less loyalty towards organisations in preference to loyalty towards their careers. Employees are also more inclined towards self-indulgence, the pursuit of leisure activities and family involvement. Thirdly, a higher degree of workplace diversity is threatening that type of trust which is formed through collaborative networks, those of place and kinship, professional membership, shared historical experiences and mutual dependencies - what Creed and Miles (1996:18) refer to as "characteristic-based" trust or, more precisely, trust "... based on norms of obligation and cooperation rooted in social similarity."

\section{Is the decline in trust cause for concern?}

Is this decline in trust something that has to be accepted as an inevitable feature of organisational life in the post-industrial era? Or are there compelling reasons for organisations to attend to this decline in trust? We believe the latter to be the case and base our conviction on the following five considerations:

- The cost of distrust

The cost of distrust to a business is mostly in the form of the control mechanisms that have to be introduced. Where trust prevails, a business relies on its employees and other stakeholders to look after and care for its assets. Where trust has been violated and employees feel betrayed by a business they will instead look for opportunities for revenge (Rossouw \& Bews 2001:29). In such a case employees can no longer be relied upon to protect the assets of the business. On the contrary, they have to be monitored continuously and all kinds of control mechanisms have to be introduced to ensure that they do not abuse their authority. This obviously is time-consuming and costly. As far as external stakeholders are concerned, distrust will equally translate into disloyalty to the organisation. This can amount to serious reputational damage to the company that can be very costly to reverse. Given these costs imposed by a lack of trust, an interest in trust makes business sense.

\section{- Participation and teamwork}

The new forms of work and organisation that have emerged in the quest to stay competitive in the global economy pose new challenges to businesses with regard to trust. With the breakdown of hierarchical structures in favour of flatter organisational structures, participative management is increasingly becoming the norm. As participative management hinges upon interaction and co-operation, it is evident that it can hardly work without a fair share of trust amongst those participating in managing the company. Trust is just as much a precondition for teamwork. Team members have to form alliances, in which goals and expertise are shared, and this also requires trust amongst team members. A lack of trust not only slows down the formation of teams but also hampers their performance. Consequently, it is clear that businesses with a stake in participative management and teamwork will have an interest in understanding and managing the process of trust formation.

\section{- The flow of knowledge}

Knowledge has become the new capital of business. The ability of an organisation to attract, use and manage knowledge is now a key determinant of its success. It has therefore become imperative that a business should succeed in gaining access to its employees' knowledge and ensuring that information flows to where it can be optimally utilised. However, access to and flow of information depends heavily on trust. As employees realise that their biggest asset is their knowledge, they will tend to protect that asset. This is even more so in situations of distrust. Trust is consequently needed to unlock these knowledge resources. Only when employees feel that they can trust others with their knowledge and expertise will they be willing to share them with others in the organisation. In this way trust facilitates the flow of information that has become so vital to the survival and success of organisations.

\section{- Loyalty}

A fourth reason for business's interest in trust relates to the potential for trust to promote co-operation and loyalty within organisations. The nature of trust is such that it always entails a relationship between at least two persons. By trusting another person one involves that person in attaining one's goals. In this way persons transcend the narrow confines of their own interests 
and share their interests with others. If the trusted person responds positively to this trust, he/she co-operates in attaining the goals of the person who invested the trust. In the case of bidirectional or mutual trust, co-operative alliances are formed around specific goals. This promotes co-operation and adds to the social cohesion within an organisation. It furthermore cultivates loyalty (Brenkert 1998:310; Rossouw \& Bews 2001:30). If managers can succeed in winning the trust of their subordinates they can expect them to be loyal to managerial goals. In this way trust inspires loyalty within the business, which may result in self-sacrificing behaviour in order to advance the interests of the organisation.

\section{- Alliances}

With the emergence of the post-industrial and the rise of globalisation, highly competitive world markets are emerging that are forcing firms to form alliances. These alliances are taking the form of collaborative agreements on research and development (R\&D) projects, long-term supply arrangements, technological exchanges and licensing accords (Powell, 1996). The trust-based governance structures of the extended business groups of the "Third Italy" and Baden Württenburg, Germany, as well as the Japanese keiretsu are prime examples. These kinds of alliances and inter-organisational co-operation presuppose relatively stable trust relationships. It is in this sense that it becomes important to understand not only intra-organisational trust but also the dynamics of the type of trust which occurs between organisations.

We believe that the above considerations make a compelling case for organisations to attend to both intra- and inter-organisational trust. This does not, however, mean that trust within and between organisations is always a good thing. One needs to be aware that like most other virtues in life, trust can also be abused and turned into a vice. It is to this darker side of trust that we will now turn.

\section{The limits of trust}

As the honouring of trust consists in the trustee's considering the trustor's interests, the impression can be created that trust equals moral behaviour, because considering another person's interests is a core element of ethical behaviour. This impression is however flawed and in need of correction. Trust can indeed be morally ambiguous (Brenkert 1998: 298; Husted 1998:233). To make sense of the moral ambiguity of trust, it is useful to distinguish between the internal and external morality thereof (Husted 1998:238).

The internal morality of trust refers to the morality of the interaction between the trustor and the trustee. In this interaction, the honouring of trust requires the trustee to respond positively to the goals that the trustor has entrusted to her/him. The honouring of trust thus entails the trustee's assisting the trustor in attaining her/his goals. It is exactly the trustee's consideration of the trustor's interests that creates the impression that the trustee behaves morally in respecting the interests of the trustor. However, the problem with this impression is that there are no constraints on what the goals of the trustor can be. If the trustor's goals are moral goals, then we can conclude that honouring the trustor's trust would amount to moral behaviour. If, however, the trustor's goals are immoral, then honouring that trust does not amount to ethical behaviour. Husted's (1998) view is thus appropriate when he warns that "... there is no element inherent in the trust relationship to assure that the trustor's good is good for the trustee" (Husted, 1998, p. 239).

The case of a fraudster who trusts another person to attain her goal illustrates the point. Thus, simply honouring the trustor's trust does not necessarily amount to ethical behaviour. Something else is needed before trust can be considered ethical. That something else that needs to be considered in adjudicating the morality of trust is its external moral dimension.
The external morality of trust refers to the impact of a trusting relationship on people (or third parties) outside that relationship. Without bringing this dimension into play the moral evaluation of trust remains incomplete. In cases where the interests of the trusting parties are advanced to the detriment of those outside that relationship, the trust involved cannot be considered moral. Once more a case of fraud is a case in point. Should a person make himself vulnerable to another person by informing and involving that person in his plans to defraud the organisation that they both work for, they both stand to benefit from this trusting relationship. Their actions will however be detrimental to the interests of all other stakeholders in that organisation and for that reason their trust relationship cannot be considered moral. However, should a trust relationship not be detrimental to the interests of third parties, then it can be considered moral.

The above discussion clearly demonstrates the moral ambiguity of trust. Trust can be both moral and immoral. As a general guideline one can say that whenever trust is used to exclude third parties or to disadvantage third parties, it constitutes a moral abuse of trust. This is the case when trust is used to protect the interests of an in-group to the detriment of all who do not belong to that in-group. Nepotism, cronyism, favouritism, racism and sexism are all examples of trust being abused to exclude third parties. Aside from being immoral, such abuse of trust can also undermine the competitiveness of businesses, as the talent pool is restricted to that of the in-group. Trust is also abused when it is used to cover up immoral practices such as fraud and corruption. In such cases the moral character of trust is eroded and it would be moral to end such trust relationships.

Flores and Solomons (1998, p. 197) are therefore correct in arguing that the complexities of trust are such that it must not be oversimplified and cannot merely be regarded as "... an efficiency booster or business tool" which is how it is often portrayed by the more popular business publications (see for instance Crandall \& Wallace, 1998; Goman, 1991; Horton \& Reid, 1991; and Reina \& Reina, 1999). Brenkert (1998, p. 301) supports this view, stating that "... it would appear that trust is not simply something of instrumental value, but also of intrinsic value".

\section{CONCLUSION}

Over the last half-decade or so, the phenomenon of trust has received a fair amount of attention. In 1996 Lewicki and Bunker $(1996$, p. 115) pointed out that "[r]emarkably little effort has been made to integrate these different perspectives or articulate the key role that trust plays in critical social process..." and, in 1998, Flores and Solomon (1998, p. 207) commented on the lack of attention trust had received in the business ethics literature.

At the time that Lewicki and Bunker made their claim, a number of works on trust, such as those by Davis, Mayer and Schoorman (1995), Mayer, Davis and Schoorman (1995) and Schoorman, Mayer, and Davis (1996), had just been released. The work Trust in organisations: Frontiers of theory and research" (Kramer \& Tyler, 1996), a whole volume dedicated to the issue of trust in which Lewicki and Bunker make their claim, was also about to be released. In recent years trust has received a great deal of attention from both social and management scientists (Bews, 2000; Dibben, 2000; Engelbrecht \& Cloete, 2000; Mayer \& Davis, 1999; Mishra \& Spreitzer, 1998; and Nooteboom, Berger \& Noorderhaven, 1997) and management consultants (Crandall \& Wallace, 1998; Reina \& Reina, 1999). Entire volumes of journals, such as the Journal of Business Ethics and the SA Journal of Industrial Psychology, have been devoted to the phenomenon of organisational change and trust. All this highlights the importance of organisational trust in contemporary society and bodes well for the development of a deeper understanding of the dynamics of trust. 
It is also our belief that the best approach to understanding trust would be an interdisciplinary approach as the nature of trust is such that it transcends any single discipline. In this regard, a coordinated effort may be required to shift the emphasis from what currently is largely a multidisciplinary approach to a more integrated interdisciplinary endeavour.

\section{REFERENCES}

Allard, T. (2000). Job figures a sign how the world churns. Sydney Morning Herald. http://www.smh.com.au/news/0003/10/ pageone/pageone12.html (22/11/2001)

Atkinson, J. (1985). The changing corporation. In D. Clutterbuck. New patterns of work. Aldershot: Gower.

Bell, D. (1973). The coming of post-industrial society: A Venture in social forecasting. New York: Basic Books.

Bews, N.F. (2000). An investigation into the facilitators of the trustworthiness of managers. Unpublished Doctoral thesis. Johannesburg: Rand Afrikaans University.

Brenkert, G.G. (1998). Trust, morality and international business. Business Ethics Quarterly, 8 (2), 293-317.

Cleary, P. (1997, October 20). Lost jobs - The downsizing of Australia. Sydney Morning Herald.

Crandall, N.F. \& Wallace, M.J. (1998). Work and rewards in the virtual workplace: A new deal for employers and employees. New York: American Management Association.

Creed, D.W.E. \& Miles, R.E. (1996). Trust in organisations: A conceptual framework linking organizational forms, managing philosophies, and the opportunity costs of controls. In R.M. Kramer \& T.R.Tyler (Eds.). Trust in organizations: Frontiers of theory and research. Thousand Oaks, CA: Sage.

Davis, J.H., Mayer, R.C. \& Schoorman, F.D. (1995). The trusted general manager and firm performance: Empirical evidence of a strategic advantage. Paper presented at the Annual Meeting of the Strategic Management Society, Mexico City.

Dibben, M.R. (2000). Exploring interpersonal trust in the entrepreneurial venture. London: MacMillan..

Drucker, P. F. (1969). The age of discontinuity. London: Heinemann.

Engelbrecht, A.S. \& Cloete, B.E. (2000). An analysis of a supervisor-subordinate trust relationship. Journal of Industrial Psychology, 26 (1), 29-38.

Financial Mail Top 100 Companies - 1997. Employment statistics give little hope. (1998). Retrieved 12 December 1998 from http://www.fm.co.za/Top100-97/job.htm

Flores, F. \& Solomon, R.C. (1998). Creating trust. Business Ethics Quarterly, 8 (2), 205-232.

Gambetta, D. (Ed.) (1988). Trust making and breaking cooperative relations. New York: Basil Blackwell.

Gini. A. (1998). Work, identity and self: How we are formed by the work we do. Journal of Business Ethics. 17 (7), 707-714.

Goman, C.K. (1991). The loyalty factor: Building trust in today's workplace. New York: Master Media.

Gonyea, J.G. \& Googins, B.K. (1996). The restructuring of work and family in the United States: A new challenge for American corporations. In S. Lewis \& J. Lewis (Eds.). The work-family challenge: Rethinking employment. London: Sage.

Hage, J. (1996). Post-Industrial lives: New demands, new perceptions. In A. Howard (Ed.). The changing nature of work. San Francisco: Jossey-Bass.

Hall, D.T. (1996). Protean careers of the 21st century. Academy of Management Executives, 10 (4), 8-16.

Hall, D.T. \& Mirvis, P.H. (1996). Careers as life long learning. In A. Howard (Ed.). The changing nature of work. San Francisco: Jossey-Bass.

Handy C.B. (1994). The age of paradox. Boston: Harvard Business School Press.

Hiltrop, J. (September, 1995). The changing psychological contract: The human resource challenge of the 1990s. European Management Journal, 13, 286-294.
Horton, R.T. \& Reid, P.C. (1991). Beyond the trust gap: Forging a new partnership between managers and their employers. Homewood, ILL: Business One Irwin.

Howard, A. (Ed.) (1996). The changing nature of work. San Francisco: Jossey-Bass.

Husted, B.W. (1998). The ethical limits of trust in business relations. Business Ethics Quarterly, 8 (2), 233-248.

Indicator South Africa. (2001). Employment trends, 18 (2), 28.

Kramer, R.M. \& Tyler, T.R. (Eds.). (1996). Trust in organizations: Frontiers of theory and research. Thousand Oaks, CA: Sage.

Kumar, K. (1995). From post-industrial to post-modern society: new theories of the contemporary world. Oxford: Blackwell.

Lattimer, R. (1996). The case for corporate diversity: An international perspective. In A. Thomas. Beyond affirmative action: Managing diversity for competitive advantage in South Africa. Randburg: Knowledge Resources.

Lewicki, R.J. \& Bunker, B.B. (1996). Developing and maintaining trust in work relationships. In R.M. Kramer \& T.R. Tyler (Eds.). Trust in organizations: Frontiers of theory and research. Thousand Oaks, CA: Sage.

Louw, I. (9 February 2001). Productivity institute tries to save jobs. Business Day (1st Edition).

Mayer, R.C., Davis, J.H. \& Schoorman, F.D. (1995). An integrative model of organizational trust. Academy of Management Review, 20 (3), 709-734.

Mayer, R.C. \& Davis, J.H. (1999). The effect of the performance appraisal system on trust for management: A field quasiexperiment. Journal of Applied Psychology, 84 (1), 123-136.

Mishra, A.K. \& Spreitzer, G.M. (1998). Explaining how survivors respond to downsizing: The role of trust, empowerment, justice and work redesign. Academy of Management Review, 23 (3).

Moss Kanter, R. (1989). When giants learn to dance. New York: Touchstone.

Nooteboom, B., Berger, H. \& Noorderhaven, N.G. (1997). Effects of trust and governance on relational risk. Academy of Management Journal, 40 (2), 308-338.

Powell, W.W. (1996). Trust-based forms of governance. In R.M. Kramer \& T.R. Tyler (Eds.). Trust in organizations. Frontiers of theory and research. Thousand Oaks, CA: Sage.

Reina, D.S. \& Reina, M.L. (1999). Trust and betrayal in the workplace: Building effective relations in your organization. San Francisco: Berrett-Koeler.

Republic of Turkey. Ministry of Foreign Affairs. Retrieved 15 December 1998 from http://inter.mfa.gov.tr/GRUPF/ turks.htm

Robbins, S.P. (1997). Essentials of organisational behaviour (5th ed.). New Jersey: Prentice Hall

Rose, M.A. (1991). The post-modern and the post-industrial. Cambridge: Cambridge University Press.

Rossouw, G. (2001). Business Ethics, Made in Africa. Cape Town: Oxford University Press.

Rossouw, D. \& Bews, N. (July 2001). Trust. People Dynamics, 2830.

Schofield, P. (1993). Managers without portfolio. Accountancy, 117 (1230), 34-38.

Schoorman, F.D., Mayer, R.C., \& Davis, J.H. (1996). Empowerment in veterinary clinics: The role of trust in delegation. Paper presented at Annual Meeting of Society for Industrial and Organizational Psychology, San Diego.

Taylor, C. (1992). The Ethics of Authenticity. MASS: Harvard University Press.

Toffler, A. (1980). The Third Wave. London: Collins.

Volk, E. (2001). Restructuring comments from the floor. South African Labour Bulletin, 25 (3), 26-27.

Von Holdt, K. \& Webster, E. (2001). Restructuring of work: examining union responses. South African Labour Bulletin, $25(3), 19-25$.

Webster, F. 1995. Theories of the information society. London: Routledge. 
SOUTH AFRICA

PRETORIA

CAPE TOWN

DURBAN

INTERNATIONAL

AUSTRALIA

BELGIUM

CANADA

CHINA

DENMARK

FINLAND

FRANCE

GERMANY

GREECE

HONG KONG

HUNGARY

INDIA

INDONESIA

IRELAND

ITALY

JAPAN

KOREA

MEXICO

NETHERLANDS

NEW ZEALAND

NORWAY

POLAND

PORTUGAL

SINGAPORE

SOUTH AFRICA

SPAIN

SWEDEN

SWITZERLAND

TURKEY

UK

USA
Making People your Competitive

\section{Advantage}

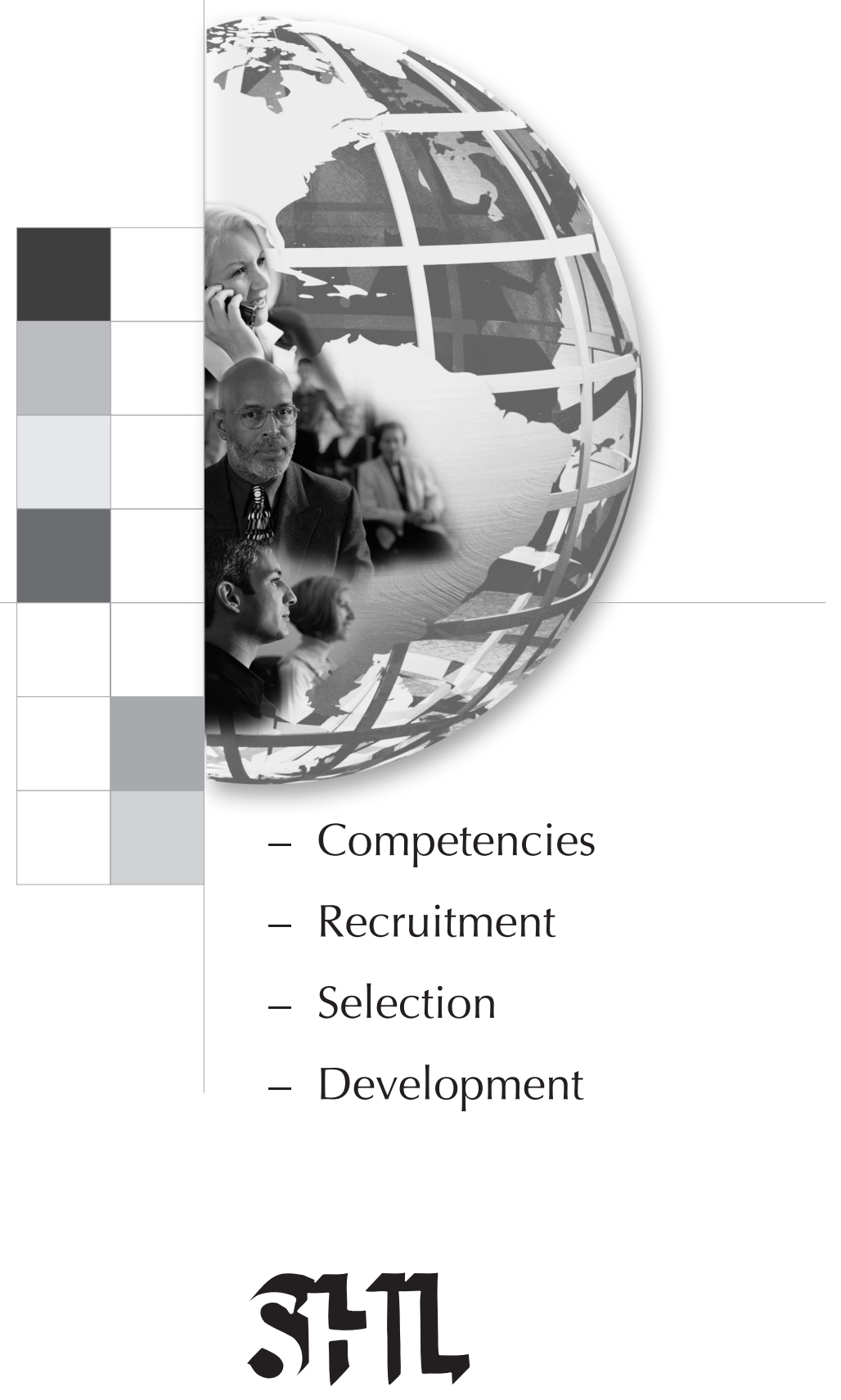

PO Box 1305 • Groenkloof • Pretoria • South Africa • 0027

Tel. $+27(0) 12346-5330 \bullet$ Fax. $+27(0) 12$ 346-5333

Email.info@shl.co.za・Internet.www.shl.co.za 